\title{
Baseline environmental impact assessment of phytodiversity in a proposed floor sweeping canalization of Abonnema Wharf adjoining water ways and Aiteo jetty development project
}

\author{
Nsirim Lucky Edwin-Wosu \\ Department of Plant Science and Biotechnology, Faculty of Biological Science, College of Natural and Applied Sciences University of \\ Port Harcourt, Choba, Port Harcourt
}

\author{
Email address: \\ nsirim.edwin-wosu@uniport.edu.ng
}

\section{To cite this article:}

Nsirim Lucky Edwin-Wosu. Baseline Environmental Impact Assessment of Phytodiversity in a Proposed Floor Sweeping Canalization of Abonnema Wharf Adjoining Water Ways and Aiteo Jetty Development Project. International Journal of Environmental Monitoring and Analysis. Vol. 2, No. 1, 2014, pp. 14-26. doi: 10.11648/j.ijema.20140201.12

\begin{abstract}
This report describes the results of an ecological baseline impact assessment study of the Aiteo operational area. This baseline has merit based on the context of a proposed canalization / floor sweeping of adjoining water ways, construction and development of a Jetty project in Abonnema Wharf Area, Port Harcourt, Rivers State. This study was aimed at establishing the existing conditions of the environment and envisaged degrees of potential impact on the area against which future changes may be assessed and secondly, reviewing the possible risks to the environment likely to arise from the canalization, construction and operation of the Jetty. A standard procedure of integrated field study was adapted to qualitatively and quantitatively assess floristic profile of the vegetation in the area. The result of the study has recorded climax mangrove forest vegetation, though with some levels of heterogeneity and discrete homogeneity as a result of imbalances in the local environmental conditions incursioned by both natural and human factors. However, the ecosystem still maintains the status of abundance, richness and evenness with obvious similarity in floristic composition and forest structure to that in tropical forest elsewhere in the world. It is obvious that the Abonnema wharf forest ecosystem is gradually being destroyed without proper articulation of its wealth of flora diversity. Its mangrove forest vegetation is variable in size, form and plant community structure. It is one of the most productive ecosystems with enormous benefits to the people in this part of Niger Delta, Nigeria, and the store house of bio- diversity providing suitable habitats for plants, important areas for rare and endangered wildlife. The application of phyto-sociological indices of assessment for the mangrove vegetation complex in terms of species diversity in richness and evenness, density, abundance, IVI, distribution pattern and defined vegetation structure has been highlighted, indicating the area to be of high conservation potential if protected from both natural and human perturbation.
\end{abstract}

Keywords: Mangrove Forest, Species Diversity, Abundance

\section{Introduction}

Socio-ecological changes are always enshrined in every developmental activity [1]. A good monitoring and evaluation system will indicate any probable changes and results of activities, including eventual impacts and the extent of the desired results achieved and their sustainability $[1,2,3]$. Therefore in order to assess the levels of impacts envisaged to emanate due to the project on the ecology of any environment, a comprehensive baseline enumeration of flora composition of the area need to be carried out. Baseline study ensures that proposed activities of development project are executed in accordance with statutory requirements and regulations. Quite a number of endemic plant species, which might be of immense economic importance to man and new to science, might abound in areas proposed for project. Thus, the need for baseline study prior to the development of such project. Furthermore, such a study will strike a balance between obtaining sufficient information to describe existing features, their inter-relationship and overall environmental status or quality, while obtaining detailed 
data on the current status and trends of vegetation to enable specific impacts be predicted [4].

Industrial interest in the continuous resource development potential of Nigerian's Niger Delta has led Aiteo Energy Resources to propose the Floor Sweeping Project of Abonnema Wharf Jetty area and adjoining water ways. In keeping with the directives from the Nigerian Ports Authority (NPA), National Inland Waterways Authority (NIWA), Federal Ministry of Environment sectorial guidelines on oil and gas industry project, State Ministry of Environment and the Department of Petroleum Resources (DPR) as well as Environmental guidelines on EIA, AITEO commissioned Environmental and Chemical Services Limited to carry out Baseline Environmental Impact Assessment Study. The preparation of the EIA will also support subsequent application and acquisition for Environmental Management Plan (EMP) and Associated Environmental permits for the project. The proposed baseline study was conducted under the context and premise of Review existing literature of the study area including study reports if any, determination and description of the vegetation type, structure and floristic composition of the study zones, and determination of the population of key species and their distribution in terms of frequency of abundance. Thus, with the aim of ; providing and establishing through biological studies appropriate ecological data on the existing status of all identifiable and associated components of vegetation biota of the people and their environ, assessment of the potential positive and negative impact of the proposed project on the environment, proposing appropriate mitigation measures to minimize negative environmental impacts arising from the project and enhance positive impact on the environment, to incorporate the recommendations and fall-out of the EIA process into detailed project design and decisions and suggesting effective environmental management plan. Thus, developing an environmental management plan (EMP) for all phases of the project development and to give confidence to the planning system by providing for public participation and for consultation processes and to help in the identification of possible alternative processes. Based on the above objectives, provide an operation plan as in surveillance network programme to monitor performance and activities of the proposed project.

\section{Materials and Methods}

\subsection{Geomorphological Description of the Study Area}

The proposed study area (Abonnema Wharf Community) is one of the most popular and oldest Jetty in Port Harcourt, the River State capital. The Abonnema Wharf originally known as Angala-Pele-Poku water ways and popularly called Bonny River is a brackish or generally a marine water ecosystem. It is an annex extension of the Bonny River and a nexus of creeks and creeklets adjoining communities on the upper belt of the Bonny River system.
Some of the creeklets end blindly in mangrove swamps while others interconnect causing the mixing of the flood and ebb tidal waters from sources. The study area is located in the coastal marine belt within the equatorial climate region, characterized by high rainfall, high relative humidity and maximum temperature. The ecosystem is characterized with a luxuriant mangrove vegetation structure with mainly members of Rhizophoraceae, Avicenniaceae and Arecaceae families typical of a mangrove vegetation structure within the Wharf and adjoining water ways, while the jetty area shoreline is characterized with members of the Amaranthaceae, Caricaceae and Portulacaceae families. The Aiteo operational base / tank farm is characterized by members of Amaranthaceae, Acanthaceae, Convolvulaceae, Lamiaceae, Asteraceae, Nyctaginaceae, Poaceae, Commelinaceae, and Cyperaceae. Other families include Rubiaceae, Caricaceae, Myrtaceae, Moraceae, Bignoniaceae, Cleomaceae, Cucurbitaceae, Sterculiaceae, Fabaceae, Piperaceae, Euphorbiceae and Solanaceae.

Though the wharf and its waterways is associated with a homogenous forest in discrete quanta and spatial vegetation continuum, while the Aiteo base is heterogeneous in structure, the effect of various forms of anthropogenic activities have consequently resulted to some level of ecological succession in a similar assertion by Hopkin [5] for a low land secondary vegetation system. Despite such ecological succession by anthropogenic influences, the vegetation can still be described as coastal mangrove vegetation in relation to similar view of vegetation analysis by SAF [6] and Edwin-Wosu, [7 - 10]

Geomorphological, the ecosystem is characterized with a sulphur smell (sulphurdioxide) silty-clays, peaty clays commonly called "Chikoko soil", saline sands and mud flat benthic sediment. These edaphic structures are under the influence of hydrological regime of the up-rising flood and ebb tidal waters. The mudflat at the ebbing tide is visibly seen to be colonized by mycoflora and blue-green algae (cyanophyta) and with the intensive sulphur smell.

The Wharf is an important hub with support for some forms of industrial development such as oil and gas and agro-allied industries in Nigeria. The zone is housing over nine major establishments (around the peripheral shores of the coastal water) with diverse business such as hydrocarbon related activities, export and import activities, production, transport logistics, pipe-coating, welding and sales, scrap recycling and haulage, and other activities, which have made significant contributions to Nigeria's economy. At its cardinal situates, the south-western location is characterized with series of hydrocarbon activities associated with the development and operations of petroleum tank farms belonging to different oil companies, such as Aiteo Energy Resource, Sorelink Oil and Dozzy Oil and Gas respectively. Similarly, the north-western location is known for its localization with the Nigerian Railway Cooperation terminal, Ibeto Cement complex, Adamac complex, the Nigerian Ports Authority (NPA) terminals and 
other sister in-house organizations etc. At the core northern location is the Isaka community with the popular Isaka Sea School (but presently known as the Isaka Sports Institute). While the south-eastern location is associated with Mass Energy and Saipem industries, the core southern location is characterized with dilapidated Anchorage jetty saddled with human activities such as logistic terminal and take-off point for navigation boats, ferry and different trading activities. The upland peripheries of the jetty also served as habitation and residence for some groups in the Riverine and upland nearby communities before the demolition exercise by the Government of Rivers State.

Socio-economically, the Abonnema Wharf has immensely influenced the tradition and culture of the riverine and lowland community dwellers. The ecosystem and its creeks serve for fishing and small aquaculture, transportation, mangrove logging, trading, waste disposal and as an avenue for beach solitude and relaxation. Besides, the mangrove canopy and moveable species underneath the shade offer the locals and shoreline inhabitant a benign environment for defecation and also habitat for aquatic lives. The Abonnema Wharf creek also serve for aquatic food harvesting with bulk of crabs Uca tangeri (fiddler crab) and Typanotonus fuscatus (periwinkle) traded in both night and daily market at Rumuwoji Mile 1 Port Harcourt.

\subsection{Qualitative and Quantitative Flora Assessment}

There are different methods and approaches to environmental impact assessment of development projects. According to Smith [11] five principal major types are commonly used, amongst which are; the checklist, interactive matrices, overlay mapping, network and simulation modeling methods. Based on heterogeneity and irregular physiognomy of the project area due to anthropogenic influences, the study area is being fragmented into two major sampling zones viz: The Abonnema Wharf Jetty Area / Adjoining Water ways (with its coordinates situate ranging between Lat. $04^{\mathrm{O}} 44^{1} 56.0^{\prime} \mathrm{N}$ \& Lat. $04^{\mathrm{O}} 46^{1} 25.5^{\prime} \mathrm{N}$ and Long. $006^{1} 59^{1} 26.1$ "E \& Long. $\left.007^{\mathrm{O}} 00^{1} 25.8^{\prime} \mathrm{E}\right)$ and The Aiteo Operational Base / Tank Farms (with its coordinates situate lying between Lat. $04^{\mathrm{O}}$ $46^{1} 31.5$ "N \& Lat. $04^{\mathrm{O}} 46^{1} 42.8^{\prime \prime} \mathrm{N}$ and Long. $006^{\mathrm{O}} 00^{1}$ 23.8 "E \& $007^{\circ} 00^{1} 23.7$ 'E). Furthermore, based on the 'Terms of Reference' (TOR) for the flora biodiversity assessment and in line with the physiognomy of the area, the 'Overlay Mapping method is being adopted using the simple random sampling based on standard procedures for ecological assessment studies [12]. A total of five substations including two controls (up-stream and downstream respectively) around the Abonnema jetty study area were systematically sampled. Each station was sampled using one $40 \times 20 \mathrm{~m}$ transect. Also at the Aiteo Operational Base / Tank Farm study area, a similar transect but containing randomly laid quadrates of $5 \times 5 \mathrm{~m}$ for shrubs, $1 \mathrm{x} 1 \mathrm{~m}$ for herbs were used. All the important representative plant species sampled were identified in the field as far as possible and were properly identified using reference books and Floras such as Burkill, [13 - 17]; Hutchinson and Dalziel, [18 - 22]; Ivens et al. [23]; Joyce and Stanfield, [24]; Joyce, [25]; Keay, [26].

\subsection{Data Analysis}

The frequency of distribution, abundance, and density of the most representative species of the area were estimated using the methods of Austin and Greig-Smith [27]; Kershaw [28] and Shukla and Chadel's [29] approach as modified in Bonham [30]. Vegetation was described in semi-quantitative terms [31], and in accordance, species with a wide frequency of distribution with many stands are described as very abundant $(++++>)$. Some species with similarly wide frequency of distribution but with few stands are said to be less frequent, abundant, or restricted species $(+++)$. The species of limited geographical distribution and with a few stands are termed scarce or occasional $(++)$ and very scarce or rare (+) species. The species designated $(++)$ and (+) are often envisaged as being vulnerable for elimination because of their limited extent alone beside any other factors. The species diversity over the study area was evaluated using the Shannon-Wiener [32] diversity index. Relative density, relative abundance and relative frequency were estimated following Misra [33] method. While the Importance Value Index (IVI) was estimated by adding the values of RD, RA and RF using the Shukla and Chandel [29] method. The ratio of abundance to frequency for different species was determined for distribution patterns. Thus with the "thumb of rule" designated as follows: Regular (<0.03), random (0.03 - 0.05), and contiguous $(>0.05)$ distribution as adopted by Curtis and Cottam [34].

\section{Result}

\subsection{Floristic Structure, Composition and Classification}

The project study area comprising the Abonnema Wharf Jetty / Adjoining Water Ways (with it cardinal situate lying between Lat. $04^{\mathrm{O}} 47^{1} 46.3^{\prime} \mathrm{N}$ \& Long. $007^{\mathrm{O}} 00^{1} 57.4^{0,} \mathrm{E}$ and Lat. $04^{\mathrm{O}} 46^{1} 42.8^{\prime \prime} \mathrm{N} \&$ Long. $\left.007^{\circ} 00^{1} 20.7^{\prime \prime} \mathrm{E}\right)$ and Aiteo operation base / Tank farm (Lat $04^{\mathrm{O}} 46^{1} 008^{\prime} \mathrm{N}$ \& Long. $006^{\mathrm{O}} 59^{1} 26.1^{\prime \prime} \mathrm{E}$ and Lat $04^{0} 44^{1} 56.0^{\prime} \mathrm{N}$ \& long $006^{0} 59^{1} 59.0$ " E) is one of the popular area in Rivers State located at the northern end of the state capital, Port Harcourt. The area under investigation is characterised by intense human activities and natural influences. Also characterised with dilapidated infrastructure such as the abandoned jetty, scraps of sea vessels (ships, canoe and boats) within the adjoining water ways and old looking tank farm within the Aiteo operation base.

The study as recorded in Tables $1 \& 2$ for the respective stations of the study area had shown that the project area is associated with secondary mosaic vegetation in spatial and vertical structure of continuum arrangement particularly with jetty adjoining water ways and heterogeneous in nature due to the biotic and abiotic influences of ecological incursion. Despite such ecological succession the study 
area was observed with plant species of various strata and categories belonging to different families with representative species of the various areas recorded based on the ecological assessment of phytosociological indices.

The Abornema Wharf Jetty / adjoining water ways being under the influence of the ebbing and uprising tide of hydrological regimes has recorded some low level secondary heterogeneity, but more dominantly in spatial continuum and vertical structure with discrete homogeneity particularly on shores. The vegetation complex recorded a total of 13 representative plant species (Table 1a) under six families with discrete homogeneity off-shores and mosaic heterogeneity particularly on-shore. Three families (Rhizophoraceae, Amaranthaceae and Portulacaceae) were prevalently dominant; with two in abundance while Amaranthaceae very abundant. Under such ecological assessment herbs and shrubs were the most dominant plant species in the study area. They were represented by seven and six species respectively distributed among the six families. Amaranthaceae was the most diverse with four species, Portulacaceae and Rhizophoraceae had three species respectively while Avicenniaceae, Arecaceae and Caricaceae had one species each.

Similar ecological assessment with the phytosociological index application on species prevalence of the study area (Table $1 b$ ) shows that among the 13 representative species, 4 species respectively have recorded a percentage frequency occurrence of $40(5.13 \%)$, while seven species respectively had $60(7.69 \%)$ and two species ( $R$. racemosa $\& R$. harizonii - red mangroves) had the highest frequency of $100(12.82 \%)$ each. The density species ${ }^{-1}$ shows that five species involving $R$. racemosa, $R$. harizonii, $R$. mangle (red mangroves); A. germinans var. africana (white mangrove) and Portulaca quadrifida (ten o'clock plant) have recorded the highest density of $20(15.15 \%)$, while $P$. oleracea (common purslane) recorded the highest abundance of 35 (15.48\%) Portulaca quadrifida recorded the highest IVI of $42.39 \%$ among the species population or prevalent status of importance.

Species diversity is one of the major criteria in recognising the importance of an area for conservation. The species diversity within and among species families have also recorded some level of variation in terms of richness and evenness. Among the dominant prevalent families two species had diversity richness of 0.05 ; four species $(0.06)$, one species $(0.07)$, one species $(0.10)$ and two species $(0.11)$ while three species ( $R$. harizonii, $R$. mangle and $P$. quadrifida) recorded the highest richness value of 0.12 respectively. Eight species have diversity evenness range of $0.05-0.09$ while five species had a range of $0.10-0.11$. The ratio of abundance to frequency in distribution pattern of species in the study area shows that all the species were contiguous in spatial distribution except Carica papaya (pawpaw) that was random in spatial distribution pattern.

In a similar study within the Aiteo operation base / tank farms, field assessment has also recorded a vegetation complex of heterogeneous nature and secondary with spatial structural arrangement. In the study area (Table 2a) a total representative of 60 species under 21 families in secondary heterogeneity and mosaic nature was recorded. Seven families (Amaranthaceae, Asteraceae, Nyctaginaceae, Poaceae, Commelinaceae, Cyperaceae and Rubiaceae) were prevalently dominant. Two families (Nyctaginaceae, and Commelinaceae) were in abundance while the remaining five families very abundant. Under such study, the life form of the species shows that Herbs and shrubs were the most dominant among species habit in the study area. 56 species were represented in herbaceous life form, while four exist as shrubs among the 21 families. However, Poaceae was the most diverse with 13 species, followed by Cyperaceae (7 species), Asteraceae and Rubiaceae has 6 species each while Amaranthaceae had 5 species and Nyctaginaceae and Commelinaceae recorded 3 species respectively. The phytosociological quantitative analysis of the study area (Table 2b), shows that among the 60 representative species, 12 species respectively have recorded a percentage frequency occurrence with a range value of $20(0-0.56 \%)$, while 27 species had values range of 40-60 (1-1.69\%) and 21 species with the highest frequency of occurrence ranging from $80-100(2-2.83 \%)$. The density, species ${ }^{-1}$ shows that 29 species recorded a density value range of $0.2-4(0-0.88 \%), 13$ species had $(1-1.97 \%) 5$ species $(2$ $-2.63 \%), 4$ species recorded $3-3.51 \%$ while the highest value of $4-4.39 \%$ were recorded among 9 species.

The species abundance have shown some level of occurrence in diverse value range with 24 species recording percentage abundance of $0-0.97 \%, 16$ species (1-1.94\%), 11 species (2-2.58\%), 4 species (3-3.88\%); and 4 species (4 $-4.30 \%$ ) while one species - Tridax procumbense (coat button) had the highest abundance value of $5.17 \%$. The importance Value Index (IVI) of species showed that four species among the representative sample had recorded importance with a value range of $0-0.91 \%$, three species had $1-1.67 \%$ IVI; Eight species $(2-2.76 \%$ IVI), while 10 species have shown importance with a value range of $3-$ $3.88 \%$ IVI. Other important value range of $4-4.58 \%, 5-$ $5.96 \%, 6-6.90 \%$ and $7-7.77 \%$ have been recorded among 12, six, four and two species respectively. Also similar species importance value showed that IVI range of $8-8.35 \%$, and $9-9.88 \%$ were recorded among two and six species respectively while four species - Eragrostis ciliaris, Eragrostis tenella, Alternanthera pungens and Diodia sarmentosa recorded the highest IVI of $10.38 \%$ respectively.

The diversity of species in the study area has shown some degree of variation in flora richness and evenness among representative samples. Result showed that ten species $-P$. maximum (Guinea grass), $T$. procumbense (coat button), $P$. lanceolatus, E. ciliaris, E. tenella (love grass), $A$. compressus (carpet grass), G. celosoides, A. pungens (khaki weed); $D$. sarmentosa and $O$. corymbosa have recorded the highest and maximum diversity richness and evenness of 0.05 and 0.03 respectively species ${ }^{-1}$. The ratio of abundance to frequency showed that the species of the study area is 
mostly contiguous in species distribution pattern with a spatial continuum of 52 species while eight species were random in their distribution pattern. Generally, in all bounding coordinates along the sampling stations there was increase in herbaceous status in terms of habit with a representative total of $63(86.30 \%)$ species as herbs and 10 $(13.70 \%)$ species as shrubs. The herbaceous increase in all study site is an indication of a primary regenerative succession which seem to be progressive toward shrubby and tree life forms.

\section{Discussion}

Habitat alteration is now among the major cause of ecosystem degradation by human and natural activities [35, $36,37]$. Despite the ecological succession the study areas still contains plant species in various diversity and abundance with representative species of various stations recorded in Tables $1 \& 2$. Ecological succession due to prevailing human factor and local environmental conditions such as hydrological dynamics has contributed to variation in floral diversity in richness and evenness of the project area in terms of the emergence of heterogeneity under stable and moderate environmental factor and discrete homogeneity of the vegetation structure under lob sided unstable environmental factor. This assertion could be reaffirmed by a macro-scale study, which has attributed species diversity richness to be a product of water energy dynamics [38]. Tropical studies have correlated the importance of moisture and related factors to species richness [39].

Similarly, changes in the gradient of species richness pattern have also been commonly explained by factors such as climate productivity and other energy related factors [40, 41, 42]; while Lomolino [43] has pointed out that many components of climate and local environments such as temperature, precipitation, seasonality and disturbance regimes vary along species amplitudinal gradient which ultimately create variation in their richness. Also the decreased shift in vegetation composition particularly at the jetty water ways may have also ensued from the anthropogenic gradient such as the devegetation exercise of expanded navigation route for sea vessels and proposed reclamation of some section of the mangrove vegetation for project by some companies around study area. Thus a decrease in abundance and diversity has been recorded among species such as Nypa fruticans in the vegetation complex.

However, the ecosystem still maintains the status of abundance, richness and evenness. This corroborates the fact that there is obvious similarity in floristic composition and forest structure and families to that reported in tropical forest elsewhere in the world [44, 45, 46, 47, 48]. The range of the number of species in tropical forests in some recent reports is from 10 to 240 species. Among such reported species numbers include Kumar [44] 38 species, Chowdhury et al. [49] 85 species, Umar [50] 87 species,
Khera et al. [51] 92 species, Devi \& Yadava [45] 123 species, Reddy et al. [52] 137 species, Krishnamurthy et al. [53] 92 species, Edwin-Wosu [8] 10 species, \& EdwinWosu [7] 240. Thus the $60 \& 13$ species recorded in this study falls within what is tenable in the tropical forest.

Diversity provides an observer a feeling of satisfaction in the natural world [54]. The species diverse mangrove swamp forest is one of the five major types of vegetation in the forest zone of Nigeria [55]. The others are the fresh water swamp forest, coastal vegetation, riparian forest and low land rainforest. This make up the tropical rainforest of southern Nigeria. Nigeria has the most extensive natural stands of mangrove in Africa with large portion (over $500,000 \mathrm{ha}$ ) of it in the Niger Delta of the country [12], and the fifth largest in the world [56]. The forest is either partially or wholly flooded throughout the year. Mounds and ridges on the ground of this forest form numerous intricate narrow channels, estuaries and creeks through which flood circulate on the forest floor. These diverse channels also provide drainage network from the forest to surrounding rivers and streams, thus regulating coastal water flow and elimination of silt, sediment and pollutants from moving water [57]. The mangrove forest vegetation is variable in size, form and plant community structure and one of the most productive ecosystems of the world. In the Niger Delta, it is the store house of biological diversity providing suitable habitats for plants, important areas for rare and endangered wildlife and enormous benefits to the people.

However, with the astronomical deforestation of the forest zones in Nigeria, the mangrove ecosystems has remained the most extensive forest zone due largely to the swampy ground on which they exist which hitherto hindered exploitation. Though, their continued existence is seriously threatened by the ingress of hydrological regimes through canalization to facilitate oil and gas activities, expansion of agriculture, domestic logging and urbanization. The Abonnema Wharf Jetty / adjoining water mangrove ecosystem is currently faced with the aforementioned problems, because as one of the major hob of oil and gas activities in the Niger Delta where available land space is scarce, industrial expansion resulting in deforestation is sine qua non.

Thus, it is obvious that the Abonnema wharf forest ecosystem is gradually being destroyed without proper articulation of its wealth of flora diversity. Species diversity studies in tropical rainforest are important to determine the process or mechanisms that maintain high diversity, species richness, species assemblages and providing data base about the number and status of the species existing in an area and their conservation [47, 52]. The usefulness of phyto-sociological indices in determining the status of different tropical forest ecosystems in terms of floristic composition, species diversity and forest structure has been recently highlighted $[58,54,46,47,59,52,60]$. These different studies independently confirmed the floristic diversity of tropical forest ecosystems in terms of species 
number, genera and families in richness and evenness, density, abundance, IVI, distribution pattern and defined vegetation structure which are all reported for the Abonnema Wharf Jetty water ways.

Species richness and frequency of occurrence is further supported by the fact that landscapes are never static, their elements are in permanent temporal and spatial flux [61, 62]. Young and Swiacki [54] stated that as the anthropogenic gaps into natural forests become numerous, the landscape pattern and species composition of that forest changes gradually. This agrees with the heterogeneity and herbaceous nature of the Aiteo base / tank farms and parts of the jetty shorelines. The greater abundance of the herbaceous species among the families is an indication of a secondary vegetation heterogeneous in nature as a result of the regeneration process with new species that were absent as adult. This could be reaffirmed by the fact that in a similar study a less degrade site could favour woody shrubs and perennial herbs while more degraded site favours annual plant species [63]. The mosaic nature of vegetation on the project site as indicated by the regenerative climax in terms of the plant species structural formation, frequency of abundance and habit is a confirmation that this zone has undergone some form of anthropogenic and natural influences. This corroborates the observation by Ahmed et al. [64] that vegetation in an anthropogenic influenced habitat are linked to ever increasing synanthropisation, which Koran [65] has attributed to a number of processes, that ensues totality of changes in plant cover as result of direct or indirect human activities. Luoto et al. [66] also reported on the loss of plant species riches and habitat connectivity due to human activities. Also studies on analysis of vegetation have been carried out particularly in terms of phytosociology, species diversity, richness and abundance across different physiognomic unit in various parts of the world $[67,68-70,71]$. This agrees with the postulation that the tropical rainforest is normally made up of intricate mixture of plants belonging to different plant families, genera and species.

However, that the importance of vegetation and / or plant community in any given environment is numerous, it may not be overemphasized. This range from erosion check, climate regulation, generation and provision of litter for organic matter, protection of the soil surface from rain splash, and direct radiant insolation, enhancement of soil aeration, protection of watershed, protection of streams and rivers from incessant siltation, and sedimentation and production of food for wild rodents, wild ruminants and birds and the provision of abode and nesting point for avian species and reptiles alike.

Understanding of flora component of our ecosystem is important in several environmental baseline and impact studies. Such investigation of vegetation (though usually undertaken as companion to other biophysical parameters) is carried out in order to establish the degree of imminent environmental vicissitudes and recovery of such envisaged ecological vagaries as could be the case with Aiteo proposed Abonnema Wharf Jetty floor sweeping project. In the event of uncontrolled and accidental hydrocarbon and effluent discharge, a preconceived knowledge of the vegetation is helpful in the determination of long and shortterm effects of such spillages on all major ecological habitats of the affected area. It will also give adequate support and facilitate the identification and assessment of associated environmental problems such as Socioeconomic implications of ecological predicament that many arise as a result of the incident.

\section{Potential and Associated Environmental Impacts and Mitigation Measures}

\subsection{Potential Impact}

The Aiteo Proposed Abonnema Wharf Jetty Floor Sweeping Project could engender some biophysical changes on the environment. In course of the jetty floor sweeping the disused and excavated materials such as the abandoned metal scrapes of sea vessels (ships, boats, canoes etc), dredged spoils and their irregular deposition either on-shore and / or off-shore might result to:

1. Loss of potential habitat for both fauna and flora of the ecosystem.

2. Loss of fauna of economic importance that could enhance recuperation of vegetation (e.g. pollinator).

3. The impact of the presence of dredging structures, equipment and its personnel.

4. The effect of a new activity on the area causing disturbance and interference in the host communities way of life

5. Damages to wildlife habitat and general loss of biodiversity.

6. The impacts of routine discharges such as solid waste and toxic organic compounds on the aquatic ecosystem or environments.

7. Alteration in the soil and water geochemistry due to pulverization of the sweeping equipment. This has a great impact on the hydrological gradient and / or dynamics of the ecosystem, and as such could result to nutrient imbalance, drastic alteration in the flora hydroponic trend and adaptability with consequent embolism and loss of greater percentage of mangrove vegetation complex.

8. There could be loss of primary vegetation been replaced by secondary colonizers and alien invasive species.

9. The excavated materials (metal scrap and dredged spoils) from the water ways, some of which if abandoned un-reclaimed or recycled from the shore lines could lead to depletion of the jetty landwards for other usage, irregularity in the physiognomy of the landscape, thus encouraging erosion, siltation, organic and inorganic deposition back to the jetty 
water ways. This consequently will result to aquatic weed proliferation that could hinder sea logistics and navigation.

10. In such an abandoned condition of excavated materials, revegetation of the floristic diversity and associated recovery of the project location resumes a very slow natural regeneration toward climax status.

11. Noise from construction work would also disturb animals

\subsection{Mitigation Measures}

1. Accidental or deliberate discharge of crude oil, effluent and other hydrocarbon into the area shall be prevented and should it happen, the area shall be quickly cleaned.

2. Fire outbreak in the area and surrounding vegetation shall be prevented.

3. The management of Aiteo shall institute a contingency plan (and should there be an existing one, need to be enforced effectively) which addresses the identification and protection of vulnerable and sensitive areas including the surrounding vegetation.

4. Vegetation clearing shall be minimized and limited to only required area (within the limit of the acquired land as this may influence negatively the existence of biodiversity of the area). Thus there is need for the creation and development of a buffer zone for fauna and flora that may have been displaced or lost their natural habitation as a result of such project.

5. Run off should be diverted to stabilized outlets to reduce problems associated with concentrated flows and velocities back to the water ways as a result of irregularity in the physiognomy of the landscape from areas cleared of vegetation.

6. Temporal erosion control techniques such as sediment barriers and revegetation should be directed towards preventing soil erosion.

7. There is need for temporal or permanent stabilization of exposed shorelines, which was provided as spoil deposition sink, following demobilization of the project.

8. Mitigation measures on solid waste disposal: Recycling of potentially valuable excavated and non buried scrap materials need to be carried out jointly by Aiteo and its project contractor. Un-recycled solid waste should be land filled.

9. Areas not directly used for the project should have the following mitigative measures viz.

- $\quad$ Vegetation will not be cut back to bare Chikoko soil and should be left to decay naturally.

- $\quad$ Overhanging mangrove species will not be cut back

- There should be no chopping or removal of mangrove species of any kind and care should be taken to avoid damage to root zones in project operations.

- Branch removal may be necessary for line of site but this will be performed so as not to adversely affect the growth characteristics of the mangrove vegetation.

- $\quad$ Exploitation of forest resources by both contractors and staff shall be prohibited. The management of Aiteo shall provide employment for the host communities by ensuring that majority of the unskilled and semi-skilled labour needed for the project execution shall be obtained from the surrounding communities.

- $\quad$ Routine inspection of jetty location and facilities shall be maintained to ensure facility integrity and guide against jetty degeneration / collapse and pollutant release on vegetations of the area.

\section{Conclusion}

This ecological baseline study of vegetation of the area for Aiteo Jetty development project is based on information from a wet season survey, which is in line with the Nigerian Ports Authority (NPA), National Inland Waterways Authority (NIWA), FMENR and DPR environmental standards. The potential wastes to be associated with the development phase include atmosphere emissions from power generation, organic and inorganic release (from production processes, sanitary and domestic wastes) on the surrounding vegetation. This report has highlighted the likely potential impacts that would arise from the development project. All environmental consequences of the project on vegetation of the area have been evaluated to ensure that mitigation measures would be effectively used to reduce the likely potential impact on the environment. This project would have only minimal impact on the immediate environment should the proposed monitoring plan and mitigation measures for the project be in line with the above mentioned regulatory bodies requirements.

\section{Recommendation}

Although the results presented herein are an indication of a maximum environmental quality within acceptable standards prior to the project development, there is need for Environmental Management Programme (EMP) to be developed as this would ensure that procedures for managing the adverse potential impacts of the proposed project on the environment are developed, established and maintained throughout the life cycle of the project.

The project contractors in line with the specifications in the EIA document should adopt a profound mitigation strategy of shoreline reinstatement and protection.

The areas stipulated for jetty sweeping purposes should be restricted to minimum, thereby minimizing impacts on biodiversity and the loss of vegetation and habitat.

There is need for control induced access in order to limit impact on wildlife, fisheries and forest resources.

There should be need for sign posts at all work sites and construction camps, warning workers against hunting and 
collecting medicinal and other valued plants (anti-bush meat policy) in course of the project.

The chikoko soil removed and stockpiled in course of sweeping and canalization should be put back in place, providing fertile ground for the fast growth of natural vegetation (secondary succession).

The above six point recommendations should therefore form the bases for the actual project implementation.
Provided that adequate preventive and control measures are built into the project design, no danger is posed to the environment and surrounding vegetation by the envisaged jetty development project. When all the factors discussed above are taken into consideration and the likely implication on both the State and National economy adequately addressed, then the project is recommended to commence.

Table 1A. Survey Estimate of Representative Species around the Abonnema Wharf Jetty / Adjoining Water Ways

\begin{tabular}{|c|c|c|c|c|c|c|}
\hline $\mathbf{S} / \mathbf{N}$ & Species & $\% \mathrm{~F}$ & Family & Habit & Common Name & Remark \\
\hline 1 & Rhizophora racemosa GFW May & 100 & Rhizophoraceae & Shrub & Red mangrove & +++++ \\
\hline 2 & Rhizophora harizonii Leechman. & 100 & Rhizophoraceae & Shrub & Red mangrove & +++++ \\
\hline 3 & Rhizophora mangle Linn. & 60 & Rhizophoraceae & Shrub & Red mangrove & +++ \\
\hline 4 & Avicenna germinans var. africana P. Beauv. & 60 & Avicenniaceae & Shrub & White mangrove & +++ \\
\hline 5 & Nypa fruticans Wurmb. & 60 & Arecaceae & Shrub & Nypa palm & +++ \\
\hline 6 & Amaranthus spinosus Linn & 60 & Amaranthaceae & Herb & Spiny amaranth & +++ \\
\hline 7 & Carica papaya Linn & 60 & Caricaceae & Shrub & Paw paw & +++ \\
\hline 8 & Portulaca asteraceae Linn & 40 & Portulacaceae & Herb & Common purslane & ++ \\
\hline 9 & Alternanthera pungens $\mathrm{H} . \mathrm{B} \& \mathrm{~K}$ & 40 & Amaranthaceae & Herb & Khaki weed & ++ \\
\hline 10 & Amaranthus virides Linn & 60 & Amaranthaceae & Herb & Wild green amaranth & +++ \\
\hline 11 & Portulaca quadrifida Linn & 40 & Portulacaceae & Herb & Ten o'clock plat & ++ \\
\hline 12 & Talinum triangulare (Jacq) Willd & 40 & Portulacaceae & Herb & Waterleaf & ++ \\
\hline 13 & Amaranthus hybridus Linn. & 60 & Amaranthaceae & Herb & Green amaranth & +++ \\
\hline
\end{tabular}

Note: + (1-25) Very scarce, ++ (26-59) Scarce, $+++(60-79)$ Abundant, $++++>(80-\alpha)$ Very abundant, NA- Not available, $\%$ F- Percentage frequency.

Table 1B. Quantitative List of Representative Species around the Abonnema Wharf Jetty / Adjoining Water Ways

\begin{tabular}{|c|c|c|c|c|c|c|c|c|c|c|c|}
\hline $\mathbf{S} / \mathbf{N}$ & Species & $\% \mathbf{F}$ & D & $\mathbf{A}$ & $\%$ RF & $\%$ RD & $\% \mathbf{R A}$ & IVI & SDR & SDE & $\mathbf{A} / \mathbf{F}$ \\
\hline 1 & Rhizophora racemosa GFW May & 100 & 20 & 20 & 12.82 & 15.15 & 8.85 & 36.82 & 0.11 & 0.10 & 0.20 \\
\hline 2 & Rhizophora harizonii Leechman. & 100 & 20 & 20 & 12.82 & 15.15 & 8.85 & 36.82 & 0.11 & 0.10 & 0.20 \\
\hline 3 & Rhizophora mangle Linn. & 60 & 20 & 33.3 & 7.69 & 15.15 & 14.73 & 37.57 & 0.12 & 0.11 & 0.56 \\
\hline 4 & Avicennia germinans var. africana Linn. & 60 & 20 & 33.3 & 7.69 & 15.15 & 14.73 & 37.57 & 0.12 & 0.11 & 0.56 \\
\hline 5 & Nypa fruticans Wurmb. & 60 & 2 & 3.3 & 7.69 & 1.52 & 1.46 & 10.67 & 0.06 & 0.05 & 0.06 \\
\hline 6 & Amarcanthus spinosus Linn & 60 & 3 & 5 & 7.69 & 2.27 & 2.21 & 12.17 & 0.06 & 0.05 & 0.08 \\
\hline 7 & Carica papaya Linn & 60 & 1.6 & 2.7 & 7.69 & 1.21 & 1.19 & 10.09 & 0.05 & 0.05 & 0.05 \\
\hline 8 & Portulaca asteraceae Linn & 40 & 14 & 35 & 5.13 & 10.61 & 15.48 & 31.22 & 0.10 & 0.09 & 0.88 \\
\hline 9 & Alternanthera pungens $\mathrm{H} . \mathrm{B} \& \mathrm{~K}$ & 40 & 3 & 7.5 & 5.13 & 2.27 & 3.32 & 10.72 & 0.06 & 0.05 & 0.19 \\
\hline 10 & Amaranthus virides Linn & 60 & 2 & 3.3 & 7.69 & 1.52 & 1.46 & 10.67 & 0.06 & 0.05 & 0.06 \\
\hline 11 & Portulaca quadrifida Linn & 40 & 20 & 50 & 5.13 & 15.15 & 22.11 & 42.39 & 0.12 & 0.11 & 1.25 \\
\hline 12 & Talinum triangulare (Jacq) Willd & 40 & 2.4 & 6 & 5.13 & 1.82 & 2.65 & 9.60 & 0.05 & 0.05 & 0.15 \\
\hline \multirow[t]{2}{*}{13} & Amaranthus hybridus Linn. & 60 & 4 & 6.7 & 5.13 & 3.03 & 2.96 & 13.68 & 0.07 & 0.06 & 0.11 \\
\hline & & 780 & 132 & 226.1 & & & & 299.99 & & & \\
\hline
\end{tabular}


Table 2A. Survey Estimate of Representative Species around the Aiteo Industrial Base / Tank Farms

\begin{tabular}{|c|c|c|c|c|c|c|}
\hline $\mathbf{S} / \mathbf{N}$ & Species & $\% \mathrm{~F}$ & Family & Habit & Common Name & Remark \\
\hline 1 & Althernanthera sessilis (Linn.) DC. & 100 & Amaranthaceae & Herb & Sessile Joyweed & ++++ \\
\hline 2 & Asystasia gangentica (Linn) T. Anders & 80 & Acanthaceae & Herb & Chinese violet & ++++ \\
\hline 3 & Ipomoea involucrata P. Beauv. & 80 & Convolulaceae & Herb & Morning glory & ++++ \\
\hline 4 & Cyathula prostrata (Linn) Blume. & 60 & Amaranthaceae & Herb & Cyathule & +++ \\
\hline 5 & Platosma africanus P. Beauv. & 60 & Lamiaceae & Herb & NA & +++ \\
\hline 6 & Sclerocarpus africanus & 60 & Asteraceae & Herb & NA & +++ \\
\hline 7 & Boerhavia coccinea Mill. & 80 & Nyetaginaceae & Herb & Red spiderling & ++++ \\
\hline 8 & Boerhavia diffusa Linn & 20 & Nyetaginaceae & Herb & Red spiderling & + \\
\hline 9 & Boerhavia erecta Linn & 40 & Nyetaginaceae & Herb & Red spiderling & ++ \\
\hline 10 & Panicum maximum Jacq & 100 & Poaceae & Herb & Guinea grass & +++++ \\
\hline 11 & Aneilema beniniense (P. Beauv) Kunth & 100 & Commelinaceae & Herb & NA & +++++ \\
\hline 12 & Commelina benghalensis $\mathrm{L}$ & 100 & Commelinaceae & Herb & Wandering Jaw & +++++ \\
\hline 13 & Lagenaria guineensis (G. Don) C. Jeffrey & 20 & Cucurbitaceae & Herb & Cucurbit & + \\
\hline 14 & Ageratum conyzoides Linn. & 100 & Asteraceae & Herb & Goat weed & +++++ \\
\hline 15 & Emilia praetermissa Milne-Redhead & 80 & Asteraceae & Herb & Mauve tassel flower & ++++ \\
\hline 16 & Emilia sonchifolia & 60 & Asteraceae & Herb & Lilac tassel flower & +++ \\
\hline 17 & Tridax procumbense $\mathrm{L}$. & 40 & Asteraceae & Herb & Coat button & ++ \\
\hline 18 & Commelina diffusa Burm. $\mathrm{f}$ & 60 & Commelinaceae & Herb & Spreading day flower & +++ \\
\hline 19 & Brachiaria deflexa (Schumach) C. E. Hubbard ex Robyns & 20 & Poaceae & Herb & Grass & + \\
\hline 20 & Brachiaria falcifera (Trin) Stapf & 60 & Poaceae & Herb & Grass & +++ \\
\hline 21 & Solenostemon monostachyus (P. Beauv) Brig & 60 & Lamiaceae & Herb & NA & +++ \\
\hline 22 & Chloris pilosa Schumach & 80 & Poaceae & Herb & Finger grass & ++++ \\
\hline 23 & Chrysopogon aciculatus (Relz) Trin. & 100 & Poaceae & Herb & Love grass & +++++ \\
\hline 24 & Digitaria horizontalis Willd & 40 & Poaceae & Herb & Digit grass & ++ \\
\hline 25 & Cyperus esculentus Linn & 20 & Cyperaceae & Herb & Yellow nutsedge & + \\
\hline 26 & Cyperus rotundus Linn & 40 & Cyperaceae & Herb & Purple nutsedge & ++ \\
\hline 27 & Mariscus alternifolius Vahl & 60 & Cyperaceae & Herb & Sedge & +++ \\
\hline 28 & Kyllinga erecta Schumach & 40 & Cyperaceae & Herb & Sedge & ++ \\
\hline 29 & Kyllinga pumila Michox & 60 & Cyperaceae & Herb & Sedge & +++ \\
\hline 30 & Kyllinga squamulata Thonn. ex Vahl & 80 & Cyperaceae & Herb & Sedge & ++++ \\
\hline 31 & Pycreus lanceolatus (Poir) C.B.Cl. & 100 & Cyperaceae & Herb & Sedge & +++++ \\
\hline 32 & Pentodon pentandrus (Schum \& Thonn.) & 40 & Rubiaceae & Herb & NA & ++ \\
\hline 33 & Eleusine indica Gaertn. & 60 & Poaceae & Herb & Bull grass & +++ \\
\hline 34 & Eragrostis ciliaris (Linn) R. Br. & 60 & Poaceae & Herb & Love grass & +++ \\
\hline 35 & Eragrostis tenella (Linn) P. Beauv. ex Schult & 60 & Poaceae & Herb & Feathery love grass & +++ \\
\hline 36 & Oplismenus burmannii (Retz) P. Beauv. & 100 & Poaceae & Herb & Grass & +++++ \\
\hline 37 & Perotis indica (Linn) O. Ktze & 100 & Poaceae & Herb & Grass & +++++ \\
\hline 38 & Paspalum conjugatum Berg & 60 & Poaceae & Herb & Sour grass & +++ \\
\hline 39 & Axonopus compressus (Sw) P. Beauv & 100 & Poaceae & Herb & Carpet grass & +++++ \\
\hline 40 & Carica papaya Linn & 20 & Caricaceae & Shrub & Paw Paw & + \\
\hline 41 & Chromolaena odorata (Linn) RM King \& Robinson & 20 & Asteraceae & Herb & Siam weed & + \\
\hline 42 & Psidium guajava Linn & 20 & Myrtaceae & Shrub & Guava & + \\
\hline 43 & Ficus exasperata Vahl & 20 & Moraceae & Shrub & Sand paper Fig plant & + \\
\hline 44 & Markhamia tomentosa (Benth) K. Schum & 20 & Bignoniaceae & Shrub & NA & + \\
\hline 45 & Cleome rutidosperma $\mathrm{DC}$ & 40 & Cleomaceae & Herb & NA & ++ \\
\hline 46 & Momordica charantia Linn & 20 & Cucurbitaceae & Herb & Africa cucumber & + \\
\hline 47 & Melochia messiflifolia & 80 & Sterculiaceae & Herb & NA & ++++ \\
\hline 48 & Mimosa pudica & 100 & Fabaceae-mimo & Herb & Sensitive plant & +++++ \\
\hline 49 & Peperomia pellucida (L) H. B \& K & 80 & Piperaceae & Herb & Cow foot & ++++ \\
\hline 50 & Euphorbia heterophylla Linn & 40 & Euphorbiaceae & Herb & Spurge weed & ++ \\
\hline 51 & Gomphrena celosoides Mart & 80 & Amaranthaceae & Herb & NA & ++++ \\
\hline 52 & Pupalia lappacea (Linn) Juss & 40 & Amaranthaceae & Herb & NA & ++ \\
\hline 53 & Trianthemia portulacastrum Linn & 40 & Aizoaceae & Herb & Horse purslane & ++ \\
\hline 54 & Alternanthera pungens $\mathrm{H} . \mathrm{B} \& \mathrm{~K}$. & 60 & Amaranthaceae & Herb & Khaki weed & +++ \\
\hline 55 & Diodia sarmentosa $\mathrm{Sw}$ & 60 & Rubiaceae & Herb & NA & +++ \\
\hline 56 & Mitracarpus villosus (Sw) DC & 40 & Rubiaceae & Herb & NA & ++ \\
\hline 57 & Oldenlandia corymbosa Linn & 100 & Rubiaceae & Herb & NA & +++++ \\
\hline 58 & Spermacoce verticillata Linn & 40 & Rubiaceae & Herb & NA & ++ \\
\hline 59 & Spermacoce ocymoides Burnif & 20 & Rubiaceae & Herb & NA & + \\
\hline 60 & Schwenckia americana Linn & 20 & Solanaceae & Herb & NA & + \\
\hline
\end{tabular}


Table 2B. Quantitative List of Representative Species around the Aiteo Industrial Base / Tank Farms

\begin{tabular}{|c|c|c|c|c|c|c|c|c|c|c|c|}
\hline $\mathbf{S} / \mathbf{N}$ & Species & $\% \mathbf{F}$ & D & $\mathbf{A}$ & $\%$ RF & $\%$ RD & $\%$ RA & IVI & SDR & SDE & $\mathbf{A} / \mathbf{F}$ \\
\hline 1 & Althernanthera sessilis (Linn.) DC. & 100 & 10 & 10 & 2.83 & 2.19 & 1.29 & 6.31 & 0.035 & 0.020 & 0.10 \\
\hline 2 & Asystasia gangentica (Linn) T. Anders & 80 & 4 & 5 & 2.26 & 0.88 & 0.65 & 3.79 & 0.025 & 0.014 & 0.06 \\
\hline 3 & Ipomoea involucrata $\mathrm{P}$. Beauv. & 80 & 2 & 2.5 & 2.26 & 0.44 & 0.32 & 3.02 & 0.020 & 0.011 & 0.03 \\
\hline 4 & Cyathula prostrata (Linn) Blume. & 60 & 12 & 20 & 1.69 & 2.63 & 2.58 & 6.90 & 0.038 & 0.021 & 0.33 \\
\hline 5 & Platosma africanus P. Beauv. & 60 & 2 & 3.3 & 1.69 & 0.44 & 0.43 & 2.56 & 0.018 & 0.010 & 0.06 \\
\hline 6 & Sclerocarpus africanus Jacq. Ex.Murr. & 60 & 6 & 10 & 1.69 & 1.32 & 1.29 & 4.30 & 0.026 & 0.015 & 0.17 \\
\hline 7 & Boerhavia coccinea Mill. & 80 & 4 & 5 & 2.26 & 0.88 & 0.65 & 3.79 & 0.025 & 0.014 & 0.06 \\
\hline 8 & Boerhavia diffusa Linn & 20 & 2 & 10 & 0.56 & 0.44 & 1.29 & 2.29 & 0.017 & 0.010 & 0.50 \\
\hline 9 & Boerhavia erecta Linn & 40 & 6 & 15 & 1.13 & 1.32 & 1.94 & 4.39 & 0.027 & 0.015 & 0.38 \\
\hline 10 & Panicum maximum Jacq & 100 & 20 & 20 & 2.83 & 4.39 & 2.58 & 9.80 & 0.049 & 0.028 & 0.20 \\
\hline 11 & Aneilema beniniense (P. Beauv) Kunth & 100 & 5 & 5 & 2.83 & 1.10 & 0.65 & 4.58 & 0.027 & 0.015 & 0.05 \\
\hline 12 & Commelina benghalensis $\mathrm{L}$ & 100 & 3 & 3 & 2.83 & 0.66 & 0.39 & 3.88 & 0.025 & 0.014 & 0.03 \\
\hline 13 & Lagenaria guineensis (G. Don) C. Jeffrey & 20 & 1 & 5 & 0.56 & 0.22 & 0.65 & 1.43 & 0.012 & 0.007 & 0.25 \\
\hline 14 & Ageratum conyzoides Linn. & 100 & 8 & 5 & 2.83 & 1.76 & 0.65 & 5.24 & 0.030 & 0.017 & 0.05 \\
\hline 15 & Emilia praetermissa Milne-Redhead & 80 & 12 & 15 & 2.26 & 2.63 & 1.94 & 6.83 & 0.038 & 0.021 & 0.19 \\
\hline 16 & Emilia sonchifolia (Linn.) DC. & 60 & 6 & 10 & 1.69 & 1.32 & 1.29 & 4.30 & 0.026 & 0.015 & 0.17 \\
\hline 17 & Tridax procumbense $\mathrm{L}$. & 40 & 16 & 40 & 1.13 & 3.51 & 5.17 & 9.81 & 0.049 & 0.028 & 1.00 \\
\hline 18 & Commelina diffusa Burm. $\mathrm{f}$ & 60 & 2 & 3.3 & 1.69 & 0.44 & 0.43 & 2.56 & 0.018 & 0.010 & 0.06 \\
\hline 19 & $\begin{array}{l}\text { Brachiaria deflexa (Schumach) C. E. Hubbard } \\
\text { ex Robyns }\end{array}$ & 20 & 4 & 20 & 0.56 & 0.88 & 2.58 & 4.02 & 0.025 & 0.014 & 1.00 \\
\hline 20 & Brachiaria falcifera (Trin) Stapf & 60 & 2 & 3.3 & 1.69 & 0.44 & 0.43 & 2.56 & 0.018 & 0.010 & 0.06 \\
\hline 21 & Solenostemon monostachyus (P. Beauv) Brig & 60 & 3 & 5 & 1.69 & 0.66 & 0.65 & 3.00 & 0.020 & 0.011 & 0.08 \\
\hline 22 & Chloris pilosa Schumach & 80 & 16 & 20 & 2.26 & 3.51 & 2.58 & 8.35 & 0.043 & 0.024 & 0.25 \\
\hline 23 & Chrysopogon aciculatus (Relz) Trin. & 100 & 2 & 2 & 2.83 & 0.44 & 0.26 & 3.53 & 0.023 & 0.013 & 0.20 \\
\hline 24 & Digitaria horizontalis Willd & 40 & 6 & 15 & 1.13 & 1.32 & 1.94 & 4.39 & 0.027 & 0.015 & 0.38 \\
\hline 25 & Cyperus esculentus Linn & 20 & 6 & 30 & 0.56 & 1.32 & 3.88 & 5.76 & 0.033 & 0.019 & 1.50 \\
\hline 26 & Cyperus rotundus Linn & 40 & 6 & 15 & 1.13 & 1.32 & 1.94 & 4.53 & 0.027 & 0.015 & 0.38 \\
\hline 27 & Mariscus alternifolius Vahl & 60 & 8 & 13.3 & 1.69 & 1.76 & 1.72 & 5.17 & 0.030 & 0.017 & 0.22 \\
\hline 28 & Kyllinga erecta Schumach & 40 & 10 & 25 & 1.13 & 2.19 & 3.23 & 6.55 & 0.036 & 0.020 & 0.63 \\
\hline 29 & Kyllinga pumila Michox & 60 & 8 & 13.3 & 1.69 & 1.76 & 1.72 & 5.17 & 0.030 & 0.017 & 0.22 \\
\hline 30 & Kyllinga squamulata Thonn. ex Vahl & 80 & 3 & 3.75 & 2.26 & 0.66 & 0.48 & 3.40 & 0.022 & 0.012 & 0.05 \\
\hline 31 & Pycreus lanceolatus (Poir) C.B.Cl. & 100 & 20 & 20 & 2.83 & 4.39 & 2.58 & 9.80 & 0.049 & 0.028 & 0.20 \\
\hline 32 & Pentodon pentandrus (Schum \& Thonn.) & 40 & 2 & 5 & 1.13 & 0.44 & 0.65 & 2.22 & 0.015 & 0.008 & 0.13 \\
\hline 33 & Eleusine indica Gaertn. & 60 & 14 & 23.3 & 1.69 & 3.07 & 3.01 & 7.77 & 0.041 & 0.023 & 0.39 \\
\hline 34 & Eragrostis ciliaris (Linn) R. Br. & 60 & 20 & 33.3 & 1.69 & 4.39 & 4.30 & 10.38 & 0.051 & 0.029 & 0.56 \\
\hline 35 & Eragrostis tenella (Linn) P. Beauv. ex Schult & 60 & 20 & 33.3 & 1.69 & 4.39 & 4.30 & 10.38 & 0.051 & 0.029 & 0.56 \\
\hline 36 & Oplismenus burmannii (Retz) P. Beauv. & 100 & 4 & 4 & 2.83 & 0.88 & 0.52 & 4.23 & 0.026 & 0.015 & 0.04 \\
\hline 37 & Perotis indica (Linn) O. Ktze & 100 & 9 & 9 & 2.83 & 1.97 & 1.16 & 5.96 & 0.034 & 0.019 & 0.09 \\
\hline 38 & Paspalum conjugatum Berg & 60 & 2 & 3.3 & 1.69 & 0.44 & 0.43 & 2.56 & 0.018 & 0.010 & 0.06 \\
\hline 39 & Axonopus compressus (Sw) P. Beauv & 100 & 20 & 20 & 2.83 & 4.39 & 2.58 & 9.80 & 0.049 & 0.028 & 0.20 \\
\hline 40 & Carica papaya Linn & 20 & 0.2 & 1 & 0.56 & 0.04 & 0.13 & 0.73 & 0.005 & 0.003 & 0.05 \\
\hline 41 & $\begin{array}{l}\text { Chromolaena odorata (Linn) RM King \& } \\
\text { Robinson }\end{array}$ & 20 & 4 & 20 & 0.56 & 0.88 & 2.58 & 4.02 & 0.025 & 0.014 & 1.00 \\
\hline 42 & Psidium guajava Linn & 20 & 0.2 & 1 & 0.56 & 0.04 & 0.13 & 0.73 & 0.005 & 0.003 & 0.05 \\
\hline 43 & Ficus exasperata Vahl & 20 & 0.4 & 2 & 0.56 & 0.09 & 0.26 & 0.91 & 0.008 & 0.004 & 0.10 \\
\hline 44 & Markhamia tomentosa (Benth) K. Schum & 20 & 0.6 & 3 & 0.56 & 0.13 & 0.39 & 1.08 & 0.010 & 0.006 & 0.15 \\
\hline 45 & Cleome rutidosperma $\mathrm{DC}$ & 40 & 3 & 7.5 & 1.13 & 0.66 & 0.97 & 2.76 & 0.018 & 0.010 & 0.19 \\
\hline 46 & Momordica charantia Linn & 20 & 0.4 & 2 & 0.56 & 0.09 & 0.26 & 0.91 & 0.008 & 0.004 & 0.10 \\
\hline 47 & Melochia messiflifolia Benth. & 80 & 6 & 7.5 & 2.26 & 1.32 & 0.97 & 4.55 & 0.027 & 0.015 & 0.09 \\
\hline 48 & Mimosa pudica Linn. & 100 & 12 & 12 & 2.83 & 2.63 & 1.55 & 7.01 & 0.038 & 0.021 & 0.12 \\
\hline 49 & Peperomia pellucida (L) H. B \& K & 80 & 16 & 20 & 2.26 & 3.51 & 2.58 & 8.35 & 0.043 & 0.024 & 0.25 \\
\hline 50 & Euphorbia heterophylla Linn & 40 & 4 & 10 & 1.13 & 0.88 & 1.29 & 3.30 & 0.022 & 0.012 & 0.25 \\
\hline 51 & Gomphrena celosoides Mart & 80 & 20 & 25 & 2.26 & 4.39 & 3.23 & 9.88 & 0.049 & 0.028 & 0.31 \\
\hline 52 & Pupalia lappacea (Linn) Juss & 40 & 8 & 20 & 1.13 & 1.76 & 2.58 & 5.47 & 0.031 & 0.017 & 0.50 \\
\hline 53 & Trianthemia portulacastrum Linn & 40 & 4 & 10 & 1.13 & 0.88 & 1.29 & 3.30 & 0.022 & 0.012 & 0.25 \\
\hline 54 & Alternanthera pungens H. B \& K. & 60 & 20 & 33.3 & 1.69 & 4.39 & 4.30 & 10.38 & 0.051 & 0.029 & 0.56 \\
\hline 55 & Diodia sarmentosa $\mathrm{Sw}$ & 60 & 20 & 33.3 & 1.69 & 4.39 & 4.30 & 10.38 & 0.051 & 0.029 & 0.56 \\
\hline 56 & Mitracarpus villosus (Sw) DC & 40 & 4 & 10 & 1.13 & 0.88 & 1.29 & 3.30 & 0.022 & 0.012 & 0.25 \\
\hline 57 & Oldenlandia corymbosa Linn & 100 & 20 & 20 & 2.83 & 4.39 & 2.58 & 9.80 & 0.049 & 0.028 & 0.20 \\
\hline 58 & Spermacoce verticillata Linn & 40 & 1 & 2.5 & 1.13 & 0.22 & 0.32 & 1.67 & 0.013 & 0.007 & 0.06 \\
\hline 59 & Spermacoce ocymoides Burnif & 20 & 4 & 20 & 0.56 & 0.88 & 2.58 & 4.02 & 0.025 & 0.014 & 1.00 \\
\hline \multirow[t]{2}{*}{60} & Schwenckia americana Linn & 20 & 2 & 10 & 0.56 & 0.44 & 1.29 & 2.29 & 0.017 & 0.010 & 0.50 \\
\hline & & 3540 & 455.8 & 774.05 & & & & 300.15 & & & \\
\hline
\end{tabular}




\section{References}

[1] Austin, M.P. and Greg-smith, P. The application of quantitative method to vegetation survey J.Ecol. Vol. 56, pp. 851- 884, 1968.

[2] Collins, R. Ecological monitoring and biodiversity surveys at the Smithsonian Tropical Research Institute Boscas Deltoro Research Station. Caribean J. Sci. Vol. 41, (3) pp. $367-373,2005$.

[3] Minter, B. A, and Collins, J.P. Ecological ethics: building a new tool kit for ecologist and biodiversity managers. Conserve. Biol. Vol. 4, pp. 1803 - 1812, 2005.

[4] Nwafor, J. C. Environmental Impact Assessment for sustainable development: The Nigerian perspective. EDPCA Publications Enugu. 2006.

[5] Hopkin, B. Vegetation of the Olakemeji Forest Reserve, Nigeria J. Eco. Vol. 56, pp. 97-115, 1968.

[6] SAF Forest Cover types of North America. Washington D.C. Society of American Foresters. 1954.

[7] Edwin-Wosu, N. L. Eco-taxonomic Baseline Assessment of vegetation of Pirigbene -Obama - Agip oil field further development project in Southern Ijaw Local Government Area, Bayelsa State. Final Draft Report, NAOC / Sydney Gate-way (Nig) Limited. October, 2010.

[8] Edwin-Wosu, N. L. Eco-taxonomic Post-impact Assessment of vegetation of GOI lake oil spillage (EIA SHEWING) Vegetation survey claim of Goi Community against Shell Petroleum Development Company (SPDC) in Gokana Local Govt. Area. 2011.

[9] Edwin-Wosu, N. L. Environmental Evaluation Study of Vegetation of the Disused Imo River, Nkpoku, Obigbo North, Ebubu Pipeline (ROW) in Rivers State / and Abia State, February, 2012. MACPHED / SPDC. Wet Season Draft Report 2012a.

[10] Edwin-Wosu, N. L. EIA Baseline Study of Vegetation / Wildlife for the OBIAFU / OBRIKOM- Indorama Eleme Fertilizer Company Limited (IEFCL) Gas Delivery Pipeline Project, August 2012. Environmental \& Chemical Services Limited / Idorama Eleme Petrochemical Company Limited $2012 b$.

[11] Smith, L. Impact assessment and sustainable resourcesmanagement. Longman Group Limited, London. 1993.

[12] Kinako, P.D.S. Ecology and conservation of natural resources. Belk publishers, Port Harcourt. Pp145. 1989.

[13] Burkill, H.M. Useful Plant of West Tropical Africa, Vol. 1 (2ed.). Royal Botanic Garden, Kew, London. 1985.

[14] Burkill, H.M. Useful Plant of West Tropical Africa, Vol. 2 (2ed.). Royal Botanic Garden, Kew, London. 1994.

[15] Burkill, H.M. Useful Plant of West Tropical Africa, Vol. 3 (2ed.). Royal Botanic Garden, Kew, London. 1995.

[16] Burkill, H.M. Useful Plant of West Tropical Africa, Vol. 4 (2ed.). Royal Botanic Garden, Kew, London, 1997.
[17] Burkill, H.M. Useful Plant of West Tropical Africa, Vol. 5 (2ed.). Royal Botanic Garden, Kew, London, 2000.

[18] Hutchinson, J. and Dalziel, J.M. Flora of West Tropical Africa, Vol. 1. (Part 1.) Crown Agents for oversea government and administrations, Millbank London. 1954.

[19] Hutchinson, J. and Dalziel, J.M. Flora of West Tropical Africa, Vol. 1. (Part 2.) Crown Agents for oversea government and administrations, Millbank London. 1958.

[20] Hutchinson, J. and Dalziel, J.M. Flora of West Tropical Africa, Vol. 2. Crown Agents for oversea government and administrations, Millbank London. 1963.

[21] Hutchinson, J. and Dalziel, J.M. Flora of West Tropical Africa, Vol. 3. (Part 1) Crown Agents for oversea government and administrations, Millbank London. 1968.

[22] Hutchinson, J. and Dalziel, J.M. Flora of West Tropical Africa, Vol.3. (Part 2.) Crown Agents for oversea government and administrations, Millbank London. 1972.

[23] Ivens, G.W. Moody, K. and Egunjobi, J.K. West African Weeds. Oxford University Press. Nigeria, 1972.

[24] Joyce, L. and Stanfield, D.P. The Flora of Nigeria Sedges (Cyperaceae). Ibadan University Press, Ibadan Nigeria, 1974.

[25] Joyce, L. Flora of Nigeria grasses. Ibadan University Press. Ibadan Nigeria, 1989.

[26] Keay, R.W.J. Trees of Nigeria. Clarendon Press, 1989.

[27] Austin, M.P. and Greg-smith, P. The application of quantitative method to vegetation survey J.Ecol. Vol. 56, pp.851-884, 1968.

[28] Kershaw, K.A. Quantitative and Dynamic Plant Ecology. $2^{\text {nd }}$ Edition, Edward Arnold, London pp 305, 1975.

[29] Shukla, S.R. and Chandel, S.P. Plant Ecology. $4^{\text {th }}$ Edn. S. Chandel and Co. Ramnagar, New Delhi - 110055.197pp. 1980.

[30] Bonham, C.D. Frequency: Measurement of Terrestrial vegetation, John Wiley and Sons Inc New York, NY pp 9096. 1989.

[31] Pryor, L.D. Australian endangered species. Eucalyptus Australian National Parks and Wildlife Services Special Publication (5) Canberra 139 pp. 1981.

[32] Shannon, C.E. and Wienner, W. The mathematical theory of communications. Urbana, Illinois: University of Illinois Press, 1949.

[33] Misra, R. Ecology Workbook. Oxford \& IBH Publishing Co. Pvt Ltd., New Delhi. 244 pp. 1968.

[34] Curtis, J.T. and Cottam, G. Plant Ecology Work Book: Laboratory field reference manual. Bugess Publishing Co., Minnesota. 193 pp. 1956.

[35] Whitfield, D.P. McLeod, D.R.A. Fielding, A.H. Broad, R.A. Evans, R.J. and Haworth, P.F. The effect of forestry on golden eagles on the Island of Mull, Western Scotland $J$. Applied Ecol. Vol. 38, pp. 1208-1220, 2002.

[36] Paciencia, M. L. B. and Prado, J. Effect of forest 
fragmentation on pteridophyte diversity in a Tropical Rainforest in Brazil. Plant Ecol., Vol. 18, No.1, pp. 87 - 104. 2005.

[37] Ecoland, Post Impact Ecological Assessment Study of the oil spillage in Bodo Creek, Rivers State. Submitted to Centre for Environment, Human Rights and Development (CEHRD). 2009.

[38] O' Brien, E.M. Whittaker, R.J. and Field, R. Climate and woody plant diversity in Southern Africa, relationships at species, genus and family levels. Ecography, Vol. 21, pp. $495-509.1989$.

[39] Brown, J.H. Species diversity. Analytical biogeography (Eds.) A.A. Myers and P.S. Giller. Chapman and Hall, London. 1988.

[40] Rohde, K. Latitudinal gradients in species diversity, the search for the primary cause. Oikos, Vol. 65, pp. 514 - 527. 1992.

[41] Wright, D.H.; Currie, D.J. and Maurer, B.A. Energy supply and patterns of species richness on local and regional scales. Species diversity in ecological communities, historical and geographical perspectives (Eds.) R.E.Ricklefs and D. Schluter. Pp $66-74$. University of Chicago Press, Chicago. 1993.

[42] Grytness, J.A. Birks, H.J.B. and Peglar, S.M. Plant species richness in Fennoscandia; evaluating relative importance of climate and history. Nordic Journal Botany Vol.19, pp. 489 $-503.1999$.

[43] Lomolino, M. V. Elevation gradient of species richness, historical and prospective views. Global Ecology and Biogeography, Vol.10, pp. 3 - 13. 2001.

[44] Kumar, H.D. Modern Concept of Ecology. $8^{\text {th }}$ Edn., Rachne Laser Set, New Dehli, Ndia, pp: 478. 1997.

[45] Devi, L.B. and Yadava, P.S. Floristic diversity assessment and vegetation analysis of tropical semievergreen forest of Manipur, North East India. Trop. Ecol., Vol. 47, pp. 89 - 98. 2006.

[46] Prasad, P.R.C. Reddy, C.S. and Dutt, C.B.S. Phytodiversity of tropical rainforest of North Andaman Islands, India. Res $J$. Forestry, Vol.1, pp. 27 - 39. 2007.

[47] Sahu, S.C. Dhal, N.K. Reddy, C.S. Pattanaik, C. and Brahmam, M. Phytosociological study of tropical dry deciduous forest of boudh district, Orissa, India. Res J. Forestry, Vol.1, pp.57 - 72. 2007.

[48] Addo-Fordjour, P. Anning, A.K. Atakora, E.A. and Agyei, P.S. Diversity and distribution of climbing plants in a semideciduous rain forest, KNUST botanic garden, Ghana. Int. J. Bot., Vol.4, pp. 186 - 195. 2008.

[49] Chowdhury, M.A.M. Huda, M.K. and Iseam, A.S.M.T. Phytodiversity of Dipterocarpus turbinatus Gaertn. F. (garjan) undergrowths at Dulahazara garjan forest, Cos's Bazar, Bangaladesh. Ind. For., Vol.126, pp. $674-684.2000$.

[50] Umar, S. A case of high tree diversity in sal (Shorea robusta) dominant lowland forest of eastern Himalayan. Floristic composition, regeneration and conservation. Curr. Sci., Vol.81, pp. 776 - 786. 2001.

[51] Khera, N. Kumar, A. Ram, J. and Tewari, A. Plant diversity assessment in relation to disturbances in mid-elevational forests of Central Himalaya, India. Trop. Eco., Vol.42, pp. 83 -95. 2001.

[52] Reddy, C.S. Babar, S. Giriraj, A. Reddy, K.N. and Rao, K.T. Structure and floristic composition of tree diversity in tropical dry deciduous forest of EASTERN Ghats, Southern Andhra Pradesh, India. Asian J. Scientific Res., Vol.1, pp. 57- 64. 2008.

[53] Krishnamurthy, Y.L. Prakasha, H.M. Nanda, A. Krishnappa, M. Dattaraja, H.S. and Suresh, H.S. Vegetation structure and floristic composition of a tropical dry deciduous forest in Bhadra wildlife Sanctuary, Karnataka, India. Trop. Ecol., Vol.51, pp. 235 - 246. 2010

[54] Young, S. and Swiacki, L.N. Surveying the forest biodiversity of Evansburg State Park: Plant community classification and species diversity assessment. Int. J. Bot., Vol.2, pp.293 - 299. 2006.

[55] NEST Nigeria's Threatened Environment: A National Profile. NEST Publication, Ibadan, Nigeria. 1997.

[56] Spalding, M., Kainuma, M., and Collins, L. World Atlas of Mangroves. The International Society for Mangrove Ecosystems (ISME), Okinawa, Japan Eaethscan Limited, Washington DC. 319pp. 2010.

[57] Asthana, D.K. and Asthana, M. Environment: Problems and Solutions. S.Chad and Co. Ltd, New Delhi, pp: 434. 2003.

[58] Upadhaya, K. Pandey, H.N. Law, P.S. and Tripathi, R.S. Diversity and population characteristics of woody species in subtropical humid forests exposed to cultural disturbances in Meghalaya, Northeast, India. Trop. Ecol., Vol.45, pp. 303 314. 2004.

[59] Agbagwa, I.O. Impact of the construction of access roads to oil well locations and flowstations on the phytodiversity of some Niger Delta floodplains. J. Applied Sci. Res., Vol.4, pp. $1876-1884.2008$.

[60] Edwin-Wosu, N. L. and Edu, E. A. B. Eco - taxonomic assessment of Plant species regeneration status in a postremediated crude oil impacted site in parts of Ibibio-I- Oil field in Ikot - Ada Udo, Ikot-Abasi Local Government Area of Akwa Ibom State, Nigeria. AJPSR, Vol.3, No.3, pp.14-23. 2013.

[61] Stemier, N. C. and Koliler, N. Effect of land scape pattern on species richness, a modeling approach. Agriculture, Ecosystem and Environment, Vol. 93, pp. 353 - 361. 2003.

[62] Brown, J. H. and Leband, D. N. Species imperilment and spatial patterns of development in the United States. Conservation Biology, Vol. 20, No.1, pp. 239 -244. 2006.

[63] Khater, C. Martin, A. and Maillet, J. Spontaneous vegetation dynamics and restoration prospects for lime stone quarries in Lebanon. Applied Vegetation Science, Vol.6, pp. 199-204. 2003.

[64] Ahmed, S.S. Ahmed, T. and Akbar, K.F. Baseline study of roadside vegetation of Lahore Islamabad motorway $\left(\mathrm{m}^{-2}\right)$ and its fertility status. Journ. of App. Sci. Vol. 4, No.2, pp. $266-270.2004$

[65] Koran, J. Man's impact upon the flora and vegetation in Central Europe. In: Holzer, W. Werger, M.J.A. Ikusina, I. (Eds.). Man's impact on vegetation Hague, Dr. W. Junk pp 277- 286. 1983. 
[66] Luoto, M. Rekolianen, S. Aakkula, J. and Pykala, J. Loss of plant species richness and habitat connectivity in grasslands associated with agricultural change in Finland Anibio Vol. 32, No.7, pp. $447-452.2003$.

[67] Ganesh, T. Ganesan, R. Devy, M.S. Davidar, R. Bawa, K. S. Assessment of plant biodiversity at a mid-elevation evergreen forest of Kala Kad- Mundane Thura Tger Reserve, Western Ghats, India. Current Sciences Vol.71, pp. 379 392. 1996.

[68] Pandey, S. K. and Shukla, R. P. Plant diversity and community patterns along the disturbance gradient in plantation forests of Sal (Shorea robusta Gaertn) Current Science Vol.77, pp. 814 - 818. 1999.
[69] Pandey, S. K. and Shukla, R. P. Plant diversity in managed Sal (Shorea robusta Gaertn) forest of Gorakhpur, India: species compositon, regeneration and conservation. Biodiversity and Conservation Vol. 12, pp. 2295 - 2319. 2003.

[70] Pandey, S. K. and Shukla, R. P. Plant community and diversity patterns within the forested landscape of northeatern U.P. Indian Forester Vol.131, pp. 1217 - 1226. 2005.

[71] Tripathi, S. L. and Shukla, R.P. Effect of clipping and grazing on the various vegetational parameters of grass-land communities of Gorakhpur. Tropical Ecology, Vol. 48, pp. $61-70.2007$. 